\section{Pesquisa qualitativa como vocação?}

Qualitative research as a vocation?

\section{Rodrigo Otávio Moretti-Pires ${ }^{1}$ \\ Douglas Francisco Kovaleski ${ }^{1}$}

${ }^{1}$ Programa de Pós Graduação em Saúde Coletiva, Universidade Federal de Santa Catarina. Florianópolis SC Brasil.rodrigo.moretti@ufsc.br

No editorial "Artigo qualitativo em foco"1 os autores defendem a abertura de "uma conversa franca" sobre publicações de artigos qualitativos. O grande problema de abrir uma conversa franca é o velho dilema entre a verdade e a perpetuação de convenções sociais para a manutenção de algumas estruturas, já que há certa tradição de se observar "[...] a ciência engendrando-se a si própria", tal como apontado por Pierre Bourdieu ${ }^{2}$, para quem a ciência é capital simbólico particular e refere-se ao "fazer ver e a fazer valer uma determinada maneira de ver". Bourdieu afirma que essas caracteristicas se manifestam, por exemplo, no financiamento e na predominância de publicações de determinados tipos de fazer ciência em detrimento de outros, defendendo que os conflitos científicos são lutas de e por poder, tratando-se de "[...] um jogo no qual as regras do jogo estão elas próprias postas em jogo”2.

Ao nos depararmos com o editorial, pensamos no risco de se privilegiar as instruções de "como fazer pesquisa" - especialmente no caso das Ciências Sociais em Saúde - sem discussão epistemológica de base, e pautada tão somente nos fatores de recusa de artigos em períodicos. Essa questão nos alertou para como é fundamental, ainda que tarde, uma revisão dos prossupostos até então utilizados na Saúde Coletiva, a começar pela divisão Quali/ quanti. Podemos pensar no que alertam Adorno \& Hokheimer ${ }^{3}$ ao referir que o problemático não é "[...] apenas a atividade, mas o sentido da ciência".

Trata-se também de uma questão de debater a origem do campo: a Saúde Coletiva constitui-se primordialmente de profissionais da saúde, formados hegemonicamente sob a égide do modelo biomédico, que é distante da complexidade da Saúde Coletiva, a qual demanda matrizes teóricas provenientes das Ciências Humanas e Sociais em diálogo com outros campos do saber. Não são os métodos que caracterizam essas matrizes teóricas. Os métodos as servem, não o contrário.

Há riscos a uma agenda de pesquisa em Saúde Coletiva pautada no pragmatismo biomédico do qual é herdeira, assim como no produtivismo neoliberal da academia, estimulado pelas agências de controle e fomento. Ou seja, um verdadeiro e perigoso afã produtivista e preocupado com a rápida resolução de problemas paira sobre a Saúde Coletiva. Há consequências nessa posição do pesquisador diante do objeto: a primeira é uma preocupação com o "fazer" extremada - responder, publicar sem refletir adequadamente e aprofundar-se teoricamente nos fenômenos sociais estudados, o que produz uma superficialidade gritante nas discussões e até mesmo nas respostas perseguidas; a outra, que é decorrente da primeira, é um direcionamento pragmático do método, que, na grande maioria das vezes, separado da teoria, destituído de uma compreensão comum às Ciências Sociais e Humanas.

Ao dividir dicotomicamente os métodos de pesquisa da Saúde Coletiva valoriza-se o fazer em detrimento do por que da pesquisa e acentua-se a compreensão do método como simples ferramenta, como prescrição. Não é o método que deve reger a pesquisa, mas os fenômenos sociais que ela analisa. Não publicar significa apenas não se enquadrar em receitas de como fazer? Entendemos que as rupturas (ou tentativas de) são necessárias para avanços do conhecimento. Dessa forma, assumimos o risco de colocar o que pensamos por mais que desagrade à "comunidade científica/ acadêmica", relembrando uma das mais célebres observações de Max Weber sobre a produção de conhecimento no mundo contemporâneo: a de que fazer ciência demanda "[...] intuição que não pode ser forçada. As ideias nos chegam quando lhes apraz, e não quando queremos"4.

\section{Referências}

1. Minayo MCS, Diniz D, Gomes R. O artigoqualitativo em foco. Cien Saude Colet 2016; 21(8):2326-2326.

2. Bourdieu P. Os usos sociais da ciência. São Paulo: Editora UNESP; 2004.

3. Adorno T, Horkheimer M. A dialética do esclarecimento. Rio de Janeiro: Ed. Jorge Zahar; 1986.

4. Weber M. A Ciência como vocação. In: Weber M. Ensaios de Sociologia. Rio de Janeiro: Zahar Editores; 1974. p.154-183.

\section{Resposta dos autores}

Rio de Janeiro, 13 de novembro de 2016

Prezados colegas Rodrigo Moretti-Pires e Douglas Francisco Kovaleski,

Em resposta à sua carta publicada acima, queremos lhes dizer que consideramos este texto como continuação do debate que provocamos com o Editorial "Artigo qualitativo em foco", publicado na Ciência 
\& Saúde Coletiva 21(8), 2016. É com prazer que como editores, mas também como autores nesta e em outras revistas, trocamos esta correspondência e lhes agradecemos. Cartas são um gênero criativo da comunicação científica e ainda muito pouco explorado no país e nós as respeitamos profundamente. É no espírito da troca genuína que replicamos algumas ideias colocadas por vocês.

Em primeiro lugar, observamos que vocês fizeram um giro argumentativo diverso do exposto em nosso Editorial. Ao invés de enfrentarem o caráter de "primeiros socorros" do texto, foram em busca das bases epistemológicas de organização do campo científico. Falar em "primeiros socorros" seria como reconhecer que há alguns problemas de fundo na arquitetura de apresentação dos artigos qualitativos que são bastante comuns e que precisam ser enfrentados.

Em segundo lugar, é preciso reconhecer que, como comentaristas, estão, em larga medida, corretos e concordamos com vocês em vários pontos de seu texto: há poder, hegemonia e modos de fazer que são resultado de padrões de dominação antes mesmo que da criatividade ou do que deve mover o espírito da pesquisa. Mas não foi isso que nos propusemos a discutir. Portanto, apesar de sensatos nos comentários, vocês não conversaram com o que lançamos no Editorial. Escrevemos sobre dicas muito simples e operacionais de como apresentar um artigo qualitativo, pressupondo que toda a fundamentação teórico-metodológica tenha sido respeitada. Falamos de divulgação científica e não das bases conceituais clássicas das ciências sociais, o que nos levaria a um curso introdutório de metodologia de pesquisa, mostrando o intenso debate científico sobre a historicidade e as contradições epistemológicas e práticas de partição entre métodos quantitativos e qualitativos, problema mencionado por vocês.

Uma terceira questão apontada pela carta é que, de certa forma, nos ativemos a regras de publicação. O caráter prático do Editorial vem da nossa crença de que existem normas consagradas que tornam a produção científica universalmente compreensível e que é preciso dominá-las para transitar o pensamento enquanto a ordem não for rompida. Ou seja, há algo básico sobre as formas de fazer pesquisa e de divulgá-la: precisamos duvidar das formas, mas também aprendê-las. É no processo de reproduzi-las que as transformamos. E para reproduzi-las ou transformá-las precisamos de alguma linguagem comum para nos comunicar: como editores, optamos pela linguagem corrente dos autores desta revista. Nossos autores organizam seus textos em métodos quantitativo e qualitativo, os mais comumente usados na área de saúde pública/saúde coletiva.
Em quarto lugar, notamos que vocês se inquietaram com nosso texto e sua linguagem direta no estilo operacional. Talvez não tenham devidamente levado em conta que assinamos como editores, e não como autores de compêndio sobre métodos de pesquisa. Como editores atuamos como "observadores" da comunidade acadêmica da área e o que escrevemos é fruto e em resposta ao que constatamos sobre as práticas de revisão por pares de nossos colegas da comunidade de pesquisa. $\mathrm{Ou}$ seja, levamos em conta o que os pareceristas dizem, o que admiram e rejeitam e o que termina sendo aceito para publicação. Mas, é preciso ficar claro que não somos nós, editores, os que prescrevemos o campo de falantes e escritores em saúde coletiva. Que seja preciso mudar certas práticas arraigadas e excludentes? Não temos dúvidas. Mas não foi o nosso propósito no texto propor esse debate.

Em quinto lugar, cremos que seria preciso distinguir a quem endereçar as críticas sobre várias questões de gestão e formação científica, tratadas por vocês: os cursos de formação em teoria social e método, as formas pelas quais as agências financiam e esperam resultados e a nós mesmos enquanto comunidade de pesquisa nos diferentes espaços de poder e saber. É por isso que os comentários sobre produtivismo ou agências de financiamento nos parecem fora de lugar na crítica ao Editorial. Não temos poderes sobre esses marcos de legitimação e de reprodução do conhecimento. Reiteramos que nosso texto teve um objetivo único: o de colaborar para a apresentação dos artigos qualitativos para a Revista Ciência \& Saúde Coletiva, que tem normas e padrões próprios; e o de contribuir para o diálogo entre autores e revisores. Conhecer as regras é desnudar o silêncio sobre as práticas.

Por fim, fica evidente que como nossos interlocutores, vocês se inquietam com o fato de a divulgação científica ser uma demanda da práxis científica, certamente muito pressionada em nosso país. Para nós, autores e editores, publicar é uma das formas mais eficientes e duradouras de nos lançarmos ao debate público, exatamente como ocorre neste caso em que nos expusemos ao escrutínio coletivo. Acreditamos que a comunicação científica seja para reproduzir práticas estabelecidas, seja para rompê-las.

Um grande agradecimento a vocês que nos permitiram, uma vez mais, esclarecer nosso ponto de vista, um entre muitos, na discussão do tema em pauta.

Maria Cecília de Souza Minayo

Debora Diniz

Romeu Gomes 